\title{
RESPONSE OF PULSES TO SEED OR SOIL APPLICATION OF RHIZOBIAL INOCULANTS
}

\author{
REAKCJA ROŚLIN STRACCZKOWYCH NA SZCZEPIONKI RIZOBIOWE \\ ZASTOSOWANE NA NASIONA LUB DOGLEBOWO
}

\begin{abstract}
In micro-plot experiments growth, nodulation and seed yields of pea, yellow lupine and soybean grown in a soil colonized by high populations of pea and lupine rhizobia and low population of soybean rhizobia as influenced by seed or soil application of rhizobial inoculants were studied. The studied inoculation method had no significant effects on root nodule numbers, plant growth at the flowering stage and on seed yields of pea and yellow lupine in comparison to uninoculated control treatments. In the case of soybean seed and soil inoculation with soybean rhizobia (Bradyrhizobium japonicum) resulted in a significant increase of nodulation intensity, fresh and dry mass of shoots at the flowering stage as well as pod numbers and soybean seed yields at harvest. Soybean grown on plots in which soil was inoculated with the symbiotic bacteria gave seed yield by about $57 \%$ higher as compared to that of soybean grown from seed inoculated with the rhizobia and by $169 \%$ higher than when this crop was grown on the control (uninoculated) plots.
\end{abstract}

Keywords: lupine, pea, soybean, inoculation, rhizobia, seed, soil

\section{Introduction}

Leguminous crops (Fabaceae) are known to form symbiotic relationships with soil bacteria, commonly called as root-nodule bacteria or rhizobia. The most important feature of this symbiosis is fixation of atmospheric nitrogen by the bacteria, located inside root nodules, for the benefit of their host plants [1, 2]. Rhizobia are ubiquitous soil microorganisms but the diversity and density of soil populations of these bacteria depend on many different factors such as: soil properties, crop rotation, agricultural practices and also to the great extent on the presence of wild species of leguminous plants in a given area $[3,4]$. For example in Poland, where soybean is not an indigenous plant and where this crop is not grown frequently soils are usually void or deficient in rhizobia nodulating soybean [5]. On the contrary, Polish soils are colonized with high populations, up to $8.5^{\cdot} 10^{5}$ cells $\mathrm{g}^{-1}$, of pea rhizobia, Rhizobium leguminosarum bv. viciae. With respect to lupine rhizobia (Bradyrhizobium spp.) most of soils in Poland also contain relatively high

\footnotetext{
${ }^{1}$ Department of Agricultural Microbiology, Institute of Soil Science and Plant Cultivation - State Research Institute, ul. Czartoryskich 8, 24-100 Puławy, Poland

${ }^{*}$ Corresponding author: sm@iung.pulawy.pl
} 
populations of these symbiotic bacteria and only in about $25 \%$ of soils low numbers or no lupine symbionts were detected [6].

Inoculation of legume seeds with commercial inoculants containing preselected strains of root-nodule bacteria is a common agriculture practice, which helps to ensure an effective symbiosis, particularly when natural soil populations of these bacteria are deficient, ineffective or only partially effective [3-7]. Response of legumes to inoculation is determined by a variety of factors such as the presence or absence of indigenous rhizobial populations in soil, soil physicochemical constrains, soil nitrogen availability and climatic conditions [5-9]. In the case of soils in which symbiotic bacteria of particular leguminous plants do not occur pre-sowing seed treatment with inoculants containing these bacteria is highly recommended and this treatment usually results in a significant yield increases [8-12]. However, when adequate numbers of effective rhizobia are present in soils, seed or soil treatment with inoculants containing symbiotic bacteria usually does not lead to improved plant growth and higher seed yields of legumes [13-15]. Results of greenhouse and field studies conducted in several countries indicate that as few as 10-20 cells of indigenous rhizobia $\mathrm{g}^{-1}$ of soil can markedly reduce or even eliminate statistically significant responses of various legumes to inoculation [7, 8]. Rhizobial inoculants are most often applied onto seeds of legumes shortly before sowing, but in-furrow soil inoculation during sowing is also possible but studies on the effectiveness of this method in comparison to seed inoculation are limited, particularly with respect to soils containing high numbers of indigenous rhizobia $[5,9,13]$.

The objective of this study was to compare growth, nodulation and seed yields of pea, yellow lupine and soybean grown on a soil colonized with high populations of pea and lupine rhizobia and low population of soybean rhizobia as influenced by seed or soil application of rhizobial inoculants.

\section{Materials and methods}

Biological materials. The symbiotic bacteria used in this study: Bradyrhizobium sp. (Lupinus) strain L93 (symbiont of lupine), Bradyrhizobium japonicum strain 94P (symbiont of soybean) and $R$. leguminosarum bv. viciae strain GGL (symbiont of pea) originated from The Culture Collection of $\mathrm{N}_{2}$-fixing Bacteria of The Department of Agricultural Microbiology, Institute of Soil Science and Plant Cultivation (ISSPC), State Research Institute in Pulawy. Stock cultures of the rhizobia were maintained at $4{ }^{\circ} \mathrm{C}$ on slants of yeast extract-mannitol agar (YEMA) supplemented with $3 \mathrm{~g} \mathrm{CaCO}_{3} \mathrm{dm}^{-3}$ [12]. To prepare seed inoculants fresh cultures of these bacteria were grown in yeast extract-mannitol broth (YEMB). Colony forming units (CFU) of the rhizobia proliferated in liquid cultures and those introduced on lupine seeds were determined by the standard plate dilution method using Congo red-YEMA medium to grow the root-nodule bacteria [12].

Polish cultivars of pulses: "Mister" - yellow lupine [Lupinus luteus (L)], "Aldana" soybean [Gycine max (L) Merrill] and "Grapis" - field pea [Pisum sativum (L)] were grown in two micro-plot experiments run in the years 2012 and 2013.

Preparation of bacterial inoculants and seed or soil inoculation. Pulverized brown coal, homogenized with $1 \%$ of calcium carbonate $\left(\mathrm{CaCO}_{3}\right)$ to adjust the $\mathrm{pH}$ to 6.6-6.8, was used as the bacterial carrier in all the preparations containing the root-nodule bacteria. The carrier material was purchased from a commercial producer of rhizobial inoculants in Walcz, Poland. Portions of moistened (5 \%) carrier $(200 \mathrm{~g})$ were weighted into 
polypropylene bags and sterilized by autoclaving in $121^{\circ} \mathrm{C}$ for $60 \mathrm{~min}$. Volumes of $40 \mathrm{~cm}^{3}$ of YEMB medium were used to culture the rhizobia in $250 \mathrm{~cm}^{3}$ Erlenmeyer flasks on a rotary shaker at $100 \mathrm{rpm}$. When liquid cultures of the bacteria were in the late log-phase of growth with approximately $2-5 \cdot 10^{10} \mathrm{CFU} \mathrm{\textrm {cm } ^ { - 3 }}$ they were removed from the shaker and then used to inoculate bags containing sterile carrier. The bags with the carrier were inoculated with cultures containing a single rhizobial strain. After inoculation the microbial preparations were incubated for 48 hours at room temperature and then used to inoculate seeds at the rate of $20 \mathrm{~g}$ per $1 \mathrm{~kg}$ of seed, which resulted in about $1-2.5 \cdot 10^{6} \mathrm{CFU}$ of the rhizobia on each seed. Seeds covered with the rhizobial inoculants were sown within 2-4 hours after inoculation. To introduce the preparations containing root-nodule bacteria into the soil on micro-plots, $50 \mathrm{~g}$ of rhizobial inoculants were mixed with $50 \mathrm{~g}$ sterile carrier and this mixture was than hand-spread at the rate of $2 \mathrm{~g}$ per $1 \mathrm{~m}$ row into each sowing furrow at seeding.

Micro-plot experiments. These experiments, arranged in a randomized split-plot design, were performed during the 2012 and 2013 growing seasons on a field at the Experimental Station belonging to the Institute of Soil Science and Plant Cultivation in Pulawy. Basic properties of the soil on this field are given in Table 1 . There were the following treatments in these experiments, with four replicated plots in each treatment: I - no inoculation, II - seed-applied rhizobial inoculants and III - soil-applied rhizobial inoculants. Approximately 24 hours before inoculation of seeds with bacterial inoculants they were treated with commercial chemical seed dressing "Sarfun". Seeds of lupine and pea were hand sown in the first decade of April and those of soybean at the end of April, each year on $1 \mathrm{~m}^{2}$ plots consisting of 3 rows spaced $30 \mathrm{~cm}$ apart $\left(100\right.$ seeds $\left.\mathrm{m}^{-2}\right)$. Three weeks before sowing the soil was fertilized with $42 \mathrm{~kg} \mathrm{ha}^{-1}$ of $\mathrm{K}$ and $20 \mathrm{~kg} \mathrm{ha}^{-1}$ of P. The plots were hand-weeded and sprayed with insecticides to control aphids as needed.

Table 1

Basic physicochemical and microbiological properties of the experimental soil (sandy loam, Haplic Luvisol)

\begin{tabular}{|c|c|c|c|c|c|c|c|}
\hline $\mathbf{C}_{\text {org. }}$ [\%] & Sand [\%] & Silt [\%] & Clay [\%] & $\begin{array}{c}\text { pH } \\
{[-]}\end{array}$ & $\begin{array}{c}\text { Number of pea } \\
\text { rhizobia } \\
\text { per gram }\end{array}$ & $\begin{array}{c}\text { Number of } \\
\text { lupine rhizobia } \\
\text { per gram }\end{array}$ & $\begin{array}{c}\text { Number of } \\
\text { soybean rhizobia } \\
\text { per gram }\end{array}$ \\
\hline 1.0 & 60 & 31 & 9 & 6.2 & $2.5 \cdot 10^{3}$ & $1.2 \cdot 10^{3}$ & 12 \\
\hline
\end{tabular}

When the legume crops were at the flowering stage five plants from each replicated plots were collected to count nodule numbers on their root systems and to assess fresh and dry mass of plants (shoots). At the physiological maturity stage all plants from the central rows were collected to determine seed yields and some yield components. All data were subjected to the analysis of variance using Anova test.

\section{Results and discussion}

As Table 1 shows the soil on which the studied pulses were grown contained relatively high numbers of pea rhizobia (Rhizobium leguminosarum bv. viciae) and lupine rhizobia [Bradyrhizobium sp. (Lupinus)], but very low numbers of rhizobia nodulating soybean (Bradyrhizobium japonicum).

These numbers are in accordance with those found in our previous studies which have shown that symbiotic bacteria of leguminous plant (pea, lupine, clover and faba bean), heaving wild relatives and a long history of cultivation in Poland, commonly occur in soils 
of our country, in contrary to soybean which is a newly introduced crop and which does not have wild relatives in Europe, and this is the main reason for limited occurrence of soybean rhizobia in this region, including Poland $[5,11]$.

Inoculants containing symbiotic bacteria of leguminous crops are usually applied by inoculation of seeds shortly before sowing [7, 8, 12]. This method is relatively efficient, easy and convenient for farmers, but it has been suggested that soil application of these preparations in planting furrow may be more efficient in improving nodulation of legumes, particularly when these crops are grown on soils with high indigenous populations of rhizobia [7, 13]. This was the case with lupine and pea rhizobia in the soil on which our experiments have been conducted (Table 1). Results presented in Tables 2 and 3 indicate that in the case of pea both seed and soil applied inoculants increased nodule numbers on pea roots and number of pods per plant as compared to the uninoculated control, but the differences were not statistically significant. Other plant growth parameters and the final seed yields of pea were similar in all the treatments. The compared inoculation methods had also no significant effect on root nodule numbers, plant growth at the flowering stage and on seed yields of yellow lupine (Tables 2 and 3). In the case of both crops, pea and lupine, soil inoculation was not superior to seed inoculation with respect to nodulation intensity, plant growth and seed yields. As mentioned above, the soil on which the microplots experiments were run contained relatively high populations of indigenous rhizobia which effectively nodulated pea and yellow lupine root systems and provided the plants with sufficient amounts of symbiotically fixed $\mathrm{N}$. This was probably the main reason for the lack of response of these crops to seed or soil inoculation with their respective rhizobia and these results are in accordance with those of previous studies [13, 14]. In our earlier experiment pre-sowing seed inoculation with a mixed inoculant containing lupine rhizobia and $A$. chroococcum had also no significant effect on nodulation and seed yields of yellow lupine grown on the same soil [15].

Table 2 Effects of seed or soil inoculation on number of root nodules, fresh and dry mass of shoots at the flowering stage (Means for 2012 and 2013)

\begin{tabular}{|c|c|c|c|}
\hline Treatments & $\begin{array}{c}\text { Number of nodules per } \\
\text { plant }\end{array}$ & $\begin{array}{c}\text { Fresh mass of shoots [g] per } \\
\text { plant }\end{array}$ & $\begin{array}{c}\text { Dry mass of shoots [g] per } \\
\text { plant }\end{array}$ \\
\hline \multicolumn{5}{|c|}{ Pea } \\
\hline No inoculation & $22.1 \mathrm{a}$ & $24.7 \mathrm{a}$ & $3.5 \mathrm{a}$ \\
\hline Seed inoculation & $24.1 \mathrm{a}$ & $25.8 \mathrm{a}$ & $3.7 \mathrm{a}$ \\
\hline Soil inoculation & $24.0 \mathrm{a}$ & $24.9 \mathrm{a}$ & $3.6 \mathrm{a}$ \\
\hline \multicolumn{7}{|c|}{ Yellow lupine } \\
\hline No inoculation & $10.2 \mathrm{a}$ & $34.0 \mathrm{a}$ & $7.5 \mathrm{a}$ \\
\hline Seed inoculation & $9.6 \mathrm{a}$ & $31.8 \mathrm{a}$ & $8.2 \mathrm{a}$ \\
\hline Soil inoculation & $9.7 \mathrm{a}$ & $32.8 \mathrm{a}$ & $5.4 \mathrm{a}$ \\
\hline \multicolumn{7}{|c|}{ Soybean } \\
\hline No inoculation & $0.26 \mathrm{a}$ & $21.6 \mathrm{a}$ & $7.3 \mathrm{~b}$ \\
\hline Seed inoculation & $4.9 \mathrm{~b}$ & $29.2 \mathrm{~b}$ & $8.7 \mathrm{c}$ \\
\hline Soil inoculation & $12.3 \mathrm{c}$ & $34.8 \mathrm{c}$ & \\
\hline
\end{tabular}

*Numbers in columns with the same letter are not significantly different at $(\alpha=0.05)$

Contrary to pea and lupine rhizobia the soil used in this study contained very low numbers of symbiotic bacteria of soybean and for this reason soybean plants were poorly nodulated (0.26 nodule/plant) in the uninoculated (K) plots (Fig. 1, Table 2). 
Effects of seed or soil inoculation on number of pods, number of seeds, and seed yields of pulses at the full ripeness stage (Means for 2012 and 2013)

\begin{tabular}{|c|c|c|c|}
\hline Treatments & Number of pods per plant & Number of seeds per pod & Seed yield [g] per plant \\
\hline \multicolumn{3}{|c|}{ Pea } \\
\hline No inoculation & $8.0 \mathrm{a}$ & $5.7 \mathrm{a}$ & $7.5 \mathrm{a}$ \\
\hline Seed inoculation & $8.2 \mathrm{a}$ & $4.8 \mathrm{a}$ & $7.7 \mathrm{a}$ \\
\hline Soil inoculation & $8.4 \mathrm{a}$ & $5.2 \mathrm{a}$ & $7.3 \mathrm{a}$ \\
\hline \multicolumn{7}{|c|}{ Yellow lupine } \\
\hline No inoculation & $13.8 \mathrm{a}$ & $3.5 \mathrm{a}$ & $4.7 \mathrm{a}$ \\
\hline Seed inoculation & $13.2 \mathrm{a}$ & $3.7 \mathrm{a}$ & $4.7 \mathrm{a}$ \\
\hline Soil inoculation & $13.8 \mathrm{a}$ & $3.5 \mathrm{a}$ & $2.1 \mathrm{a}$ \\
\hline \multicolumn{3}{|l|}{ Soybean } \\
\hline No inoculation & $8.7 \mathrm{a}$ & $1.9 \mathrm{a}$ & $3.5 \mathrm{~b}$ \\
\hline Seed inoculation & $12.2 \mathrm{~b}$ & $1.9 \mathrm{a}$ & $5.5 \mathrm{c}$ \\
\hline Soil inoculation & $17.4 \mathrm{c}$ & $2.0 \mathrm{a}$ & \\
\hline
\end{tabular}

*Numbers in columns with the same letter are not significantly different at $(\alpha=0.05)$

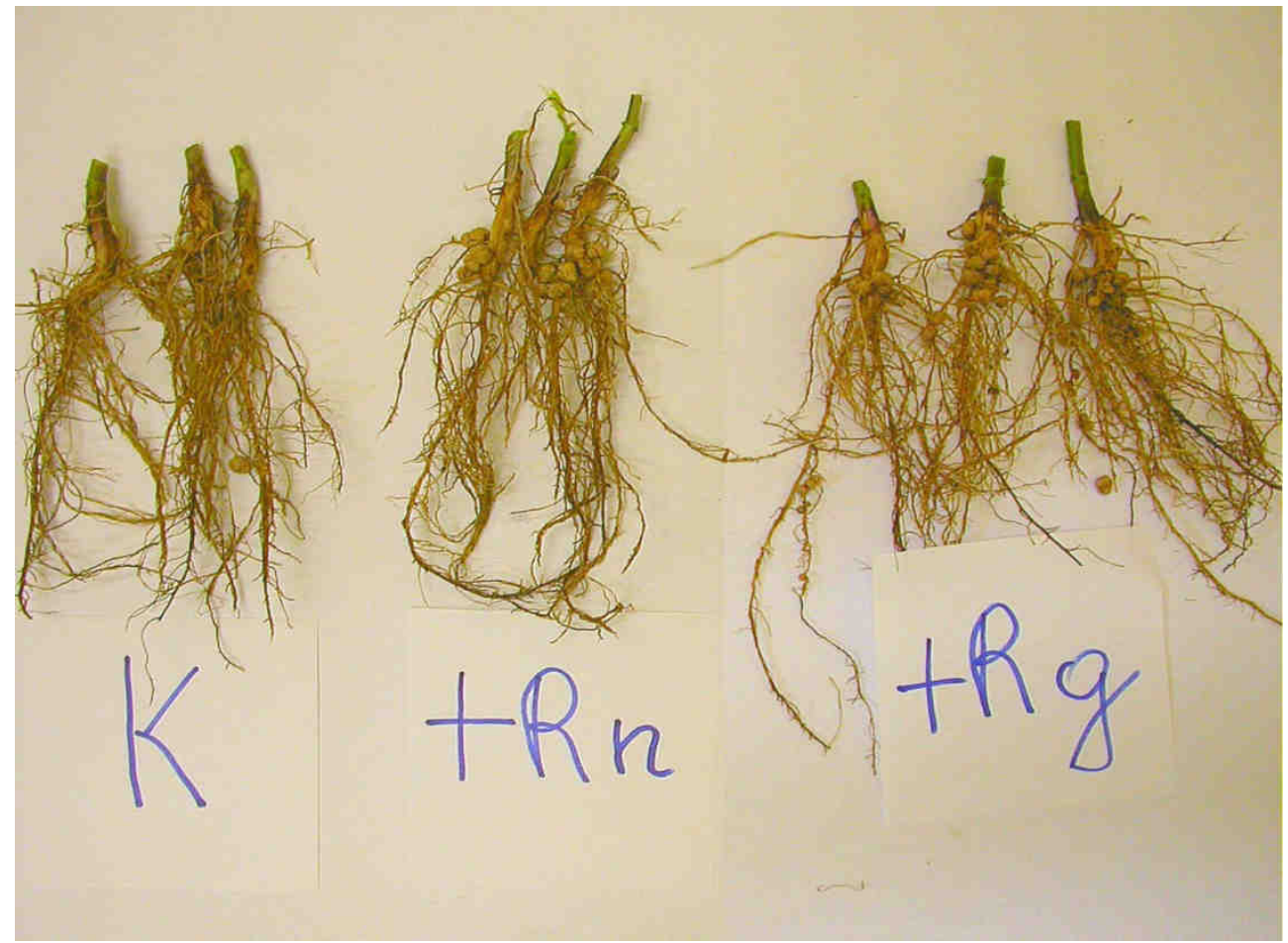

Fig. 1. Symbiotic nodules on soybean roots taken from the following treatments: uninoculated control $(\mathrm{K})$, seed applied inoculant $(+\mathrm{Rn})$ and soil applied inoculant $(+\mathrm{Rg})$

Seed and soil inoculation with soybean rhizobia resulted in a significant increase of nodulation intensity, fresh and dry mass of shoots at the flowering stage as well as pod number per plant and soybean seed yield per plant at harvest (Tables 2 and 3). Presowing 
soybean seed inoculation resulted in about $66 \%$ higher seed yield as compared to that of the uninoculated soybean (Table 3). This increase was similar to that found for soybean in our previous experiments in which soybean seeds had been inoculated with rhizobia alone [12]. However, when soybean seeds had been inoculated before sowing with the mixed inoculant containing soybean rhizobia and Azotobacter chroococcum the seed yield increase was higher and reached almost $70 \%$ [12]. In the present experiments the highest values of all the plant parameters measured, except seed number per pod, were obtained for soybean grown on plots with soil inoculated with the rhizobia and these values were significantly higher than those obtained for seed inoculated soybean, indicating that in the case of this crop soil inoculation was more efficient in improving nodulation and plant growth than seed inoculation. Results presented in Table 3 show that soybean grown on plots in which soil was inoculated with the symbiotic bacteria gave seed yield by about $57 \%$ higher as compared to that grown from seed inoculated with the rhizobia and by $169 \%$ higher than soybean grown on the control (uninoculated) plots.

Figure 1 shows that soybean plants taken from the seed inoculated plots $(+\mathrm{Rn})$ and from the soil inoculated plots $(+R g)$ had similar numbers of symbiotic nodules on the upper part of the tap roots, but $+\mathrm{Rg}$ soybean plants had more nodules on lateral roots. By "in-furrow" application of inoculants larger soil volume is inoculated with introduced bacteria [5, 13] and this was probably the main factor responsible for more intensive nodulation of soybean roots and in consequence for much higher seed yield of soybean in this treatment as compared to seed inoculation. This finding indicating that soil inoculation was more efficient in stimulation of soybean nodulation and yields than seed inoculation with root-nodule bacteria may be important also from practical point of view. However, soil application of rhizobial inoculants, e.g. into the furrow at seeding, would require liquid inoculants and special spraying devices which are not available for farmers at the present. For this reason, presowing pelleting of legume seeds with solid-state inoculants commonly available on the market is still the main method of application of rhizobial inoculants in agricultural practice.

\section{Conclusions}

Nodulation, plant growth and seed yields of pea and yellow lupine grown on soil containing relatively high populations of pea and lupine rhizobia were not significantly improved by seed or soil inoculation with the rhizobia as compared to uninoculated control treatments. In the case of soybean both seed and soil applied inoculants containing symbiotic bacteria (B. japonicum) significantly increased nodulation and seed yields of this legume crop grown in the soil containing very low numbers of soybean rhizobia. It was proved that soil inoculation was much more efficient in improving soybean nodulation and yields than seed inoculation, as indicated by about $57 \%$ higher yields of soybean grown on plots with soil applied rhizobial inoculant as compared to that grown on plots with seed applied rhizobia.

\section{References}

[1] Graham PH. Ecology of the root-nodule bacteria of legumes. In: Dilworth MJ, James EK, Sprent JI, editors. Nitrogen-fixing Leguminous Symbiosis. Dordrecht: Springer; 2008:23-58. DOI: 10.1007/978-1-4020-3548-7_2.

[2] Franche C, Lindström K, Elmerich C. Nitrogen-fixing bacteria associated with legumes and non-leguminous plants. Plant Soil. 2009;321:35-59. DOI: 10.1007/s11104-008-9833-8. 
[3] Sadowsky MJ. Soil stress factors influencing symbiotic nitrogen fixation. In: Werner D, Newton WE editors. Nitrogen Fixation in Agriculture, Forestry and the Environment. Dordrecht: Springer; 2005:89-112. https://link.springer.com/chapter/10.1007\%2F1-4020-3544-6_6.

[4] Roberts R, Jackson RW, Mauchline TH, Hirsh PR, Shaw LJ, Doring TF, et al. Is there sufficient Ensifer and Rhizobium species diversity in UK farmland soils to support red clover (Trifolium pretense), white clover (T. repens), lucerene (Medicago sativa) and black medic (M. lupulina)? Appl Soil Ecol. 2017,120:35-43. DOI: 10.1016/j.apsoil.2017.06.030

[5] Narożna D, Pudełko K, Króliczek J, Golińska B, Sugawara M, Mądrzak CJ, et al. Survival and competitiveness of Bradyrhizobium japonicum strains 20 years after introduction into field locations in Poland. Appl Environ Microbiol. 2015;81:5552-5559. DOI:10.1128/AEM.01399-15.

[6] Wielbo J, Podleśna A, Kidaj D, Podleśny J, Skorupska A. The diversity of pea microsymbionts in various types of soils and their effects on plant host productivity. Microbes Environ. 2015;30(3):254-261. DOI: 10.1264/jsme2.ME14141.

[7] Deaker R, Roughley RJ, Kennedy IR. Legume seed inoculation technology - a review. Soil Biol Biochem. 2004;36:1275-1288. DOI: 10.1016/j.soilbio.2004.04.009.

[8] Graham PH, Vance CP. Legumes: importance and constrains to greater use. Pl Physiol. 2003;131:872-877. DOI: $10.1104 / p p .017004$.

[9] Thies J, Singleton PW, Bohlool BB. Influence of the size of indigenous rhizobial populations on establishment and symbiotic performance of introduced rhizobia on field-grown legumes. Appl Environ Microbiol. 1991;57:19-28. DOI: 0099-2240/91/010019-10\$02.00/0.

[10] Hungria M, Loureiro MF, Mendes IC, Campo RJ, Graham PH. Inoculant Preparation, Production and Application. In: Werner D, Newton WE, editors. Nitrogen Fixation in Agriculture, Forestry and the Environment. Dordrecht: Springer; 2005:223-254. https://www.researchgate.net/profile/ Mariangela_Hungria/publication/226138792_Inoculant_Preparation_Production_and_Application/links/56ca b13708ae96cdd06e0cbe/Inoculant-Preparation-Production-and-Application.pdf.

[11] Albareda M, Rodriguea-Navarro DN, Temprano F. Soybean inoculation: dose, N fertilizer supplementation and rhizobia persistence in soil. Field Crops Res. 2009;113:352-356. DOI: 10.1016/j.fcr.2009.05.013.

[12] Kozieł M, Gębala B, Martyniuk S. Response of soybean to seed inoculation with Bradyrhizobium japonicum and with mixed inoculants of B. japonicum and Azotobacter chroococcum. Pol J Microbiol. 2013;62(4):457-460. www.pjm.microbiology.pl/archive/vol6242013457.pdf.

[13] Jensen ES. Inoculation of pea by application of Rhizobium in the planting furrow. Plant Soil. 1987;97:63-70. DOI: 10.1007/BF02149824.

[14] Cheminingwa GN, Vessey JK. The abundance and efficacy of Rhizobium leguminosarum bv. viciae in cultivated soils of the eastern Canadian prairie. Soil Biol Biochem. 2006;38:294-302. DOI: 10.1016/j.soilbio.2005.05.007.

[15] Martyniuk S, Kozieł M, Stalęga J. Wpływ różnych szczepów bakterii symbiotycznych na plony i brodawkowanie łubinu $\mathrm{i}$ soi (Effect of various strains of symbiotic bacteria on yields and nodulation of lupine and soybean). J Res Applic Agric Eng. 2013;58(4):67-70. http://www.pimr.poznan.pl/biul/2013_4_14MKS.pdf. 